INVESTIGACIONES

\title{
REPRESENTACIONES SOCIALES SOBRE HETEROSEXUALIDAD Y HOMOSEXUALIDAD DE LOS/LAS ESTUDIANTES DE PEDAGOGIA EN LOS CONTEXTOS DE FORMACION DOCENTE INICIAL
}

\author{
Social representations on heterosexuality and homosexuality of/the students of pedagogy \\ in the contexts of initial educational formation
}

\author{
Verónica Alejandra Lizana Muñoz \\ El Colibrí \# 91, Departamento 31, Condominio Florida Once, La Florida, Santiago. \\ Región Metropolitana, Chile. \\ valizana@puc.cl, valizana@gmail.com
}

\section{Resumen}

La pregunta de investigación ¿cuáles son las operaciones representacionales y experiencias identitarias sobre heterosexualidad y homosexualidad de los/las estudiantes de pedagogía en los contextos de Formación Docente Inicial? intenta describir, interpretar y analizar quiénes son estos actores sociales y cómo (re)construyen estas prácticas discursivas en los contextos y procesos formativos. Estos hallazgos de investigación constituyen un extracto de la Tesis de Magíster en Estudios de Género y Cultura en América Latina mención Humanidades, "Representaciones sociales sobre masculinidad, feminidad, heterosexualidad y homosexualidad de los/las estudiantes de pedagogía en los contextos de Formación Docente Inicial", presentada el año 2007 en la Universidad de Chile.

Palabras clave: formación docente inicial, género, heterosexualidad, homosexualidad.

\begin{abstract}
The investigation questions which are the representations operations and identities experiences on heterosexuality and homosexuality of/the students of pedagogy, in the contexts of Initial Educational Formation? It tries to describe, to interpret and to analyze who are these social actors, and how they construct to these discursive practices in the contexts and formative processes. These findings of investigation constitute an extract of the Thesis of Master in Studies of Sort and Culture in Latin America mention Humanities, "Social representations on masculine, feminine, heterosexuality and homosexuality of/the students of pedagogy, in the contexts of Initial Educational Formation", presented/displayed year 2007, in the University of Chile.
\end{abstract}

Key words: initial educational formation, sort, heterosexuality, homosexuality. 


\section{MARCO DE REFERENCIA}

Desde la década de los noventa, en Chile comienzan "los procesos de acreditación" de las instituciones formadoras de docentes, los que instalan "ciertos criterios de evaluación y/o estándares de calidad" para la formación personal, académica, profesional y social de los/las futuros/as profesores/as. Al respecto, se entiende que "la modernización de las políticas" de gestión, organización y funcionamiento institucional y "la actualización de la teoría-praxis" del conocimiento pedagógico e (inter)disciplinar favorece la pertinencia de los contextos socioeducativos, la consistencia de los procesos formativos, el estatus del ejercicio docente y los itinerarios-trayectorias profesionales de sus actores protagónicos/as. Por consiguiente, las líneas de formación, enfoques curriculares y perfiles de egreso de las carreras pedagógicas procuran articular los cambios socioculturales presentes en la región, los avances científicos y tecnológicos y las necesidades, intereses y expectativas de las nuevas generaciones (Avalos 2002; Cox 2003).

Atendiendo a estos cambios surge el Plan de Desarrollo Estratégico 2006-2010, que intenta vincular a los actores educativos, renovar el cuerpo académico de las instituciones formadoras de profesores/as y alinear las competencias personales, académicas, profesionales y sociales de los/las docentes con estándares de desempeño. De este modo, la difusión pública de los resultados académicos de los/las estudiantes, el impacto de la evaluación docente y los parámetros para la formación inicial y continua del profesorado se han configurado en "los nuevos referentes de la calidad educativa". En este tenor, "los/las docentes como profesionales de la educación" están convocados/as a evaluar "la eficacia-validez" de sus prácticas de enseñanza y procesos de aprendizaje, y "la eficienciavigencia" de sus conocimientos, competencias y actitudes, pedagógicas, (inter)disciplinares, metodológicas e investigativas (Ministerio de Educación, Universidad Alberto Hurtado y Universidad Católica de Valparaíso 2006).

Si bien se observan avances en las políticas educativas, el Informe de la Comisión sobre Formación Docente Inicial señala la persistencia de nudos críticos en la gestión institucional, el currículo de formación y los actores del proceso formativo. Al respecto, se evidencia que las necesidades, intereses y expectativas, personales, académicas, profesionales y sociales de los/las estudiantes de pedagogía son antecedentes desconocidos o poco relevados en la formación docente. Estas instituciones de educación superior no incrementan su autonomía, reflexión y pensamiento crítico, ni tampoco entregan la formación pedagógica e (inter)disciplinaria necesaria para sus futuras prácticas de enseñanza y procesos de aprendizaje. Estos obstáculos se suman a las bajas expectativas de los/las formadores/as de docentes y a una disminución de las exigencias académicas para retener a los/las matriculados/as (Cárdenas 2001; MINEDUC 2005).

Por consiguiente, la Formación Docente Inicial no influye en los procesos de objetivación y de subjetivación de los/las estudiantes de pedagogía, es decir, en sus operaciones representacionales o modelos explicativos sobre los modos de ser-hacer-saber-decir, y en sus experiencias identitarias o unidades de sentido sobre las imágenes-apariencias-reacciones de sí mismos/as. Esta formación no logra "empoderarlos/as como actores protagónicos/as del Sistema Nacional de Educación”, puesto que (re)producen los conocimientos, competencias y actitudes aprehendidas durante su experiencia escolar, y distribuyen los (pre) juicios sexistas, clasistas y étnicos de la sociedad chilena. Esta situación devela la necesidad de describir, interpretar y analizar ¿quiénes son los/las estudiantes de pedagogía y cómo (re)construyen estas prácticas discursivas en los contextos y procesos formativos? 
Con respecto a la primera pregunta, las últimas investigaciones advierten un mayor interés de los/las jóvenes egresados/as de enseñanza media o secundaria por ingresar a las carreras de pedagogía. Asimismo, las pruebas estandarizadas de medición evidencian un aumento significativo en los niveles de calificación de estos/as estudiantes, que considera los resultados académicos obtenidos en la etapa escolar, como los alcanzados en la Prueba de Selección Universitaria, PSU. Sin embargo, los exámenes de admisión de las instituciones formadoras de docentes develan un descenso en las Habilidades Básicas de Lenguaje y Matemáticas, por lo que han implementado "programas compensatorios o de nivelación" en estos dominios (Avalos 2002; MINEDUC 2005).

Referente a los niveles de retención de los/las estudiantes de pedagogía se observa una oscilación del $77 \%$ en todas las carreras, lo que es consistente con las disminuciones presentadas en sus niveles de egreso y titulación. Esta situación evidencia una desvalorización hacia esta carrera, dado que se constituye "en un trampolín para saltar" o "en una plataforma para alcanzar" otras de mayor honor, valor y prestigio social. Sobre la situación socioeconómica, el Sistema de Postulación al Crédito Universitario señala que en el proceso de admisión 2005, los/las 7.726 matriculados/as en las carreras pedagógicas de las Universidades del Consejo de Rectores, un $38 \%$ pertenece a los quintiles I y II, es decir, proceden de familias con un ingreso mensual per cápita inferior a 67.658 pesos (136 dólares aproximadamente) y un $16,7 \%$ pertenece al quintil III, con un ingreso inferior a los 106.867 pesos (220 dólares aproximadamente). Asimismo, se manifiesta que los años de permanencia y los resultados académicos se incrementan en la medida que estos/as estudiantes reciben ayudas estatales o becas (Avalos 2002; MINEDUC 2005).

En relación a la segunda pregunta, los estudios especializados señalan "la persistencia de una perspectiva académica, técnica e instrumental" en la Formación Docente Inicial. Esta visión privilegia "la neutralidad-aséptica de las intervenciones curriculares y la tecnificación-especializada de las prácticas pedagógicas", en desmedro de "la enseñanza reflexiva, el aprendizaje significativo y el tratamiento de la diversidad étnica, de clase y género". Por su parte, las resistencias al cambio de estos actores sociales se explican principalmente porque los espacios de reflexión relativos a las implicancias éticas de la profesión docente y los procesos de (re)significación referentes a las especificidades del contexto socioeducativo constituyen una proporción menor dentro de la misma. Igualmente, el eclecticismo ideológico en las líneas de formación, enfoques curriculares y perfiles de egreso, la fragmentación estructural del entorno institucional y del sistema organizacional termina por obstaculizar la coordinación-consistencia y coherencia-atingencia de las propuestas y programas formativos. Una desconexión entre áreas disciplinares, cátedras y/o asignaturas, donde se "sobreentiende" que los/las estudiantes de pedagogía son los/las encargados/as de integrar y articular en sus futuras prácticas pedagógicas. (Zeichner y Liston 1995; Pérez 1996; Kemmis 1999; Cárdenas 2001; Vaillant 2005; MINEDUC 2005).

Por ello, se sugiere incorporar ciertas concepciones epistemológicas, ontológicas, axiológicas y éticas en la formación personal, académica, profesional y social de los/las futuros/as profesores/as, de modo que articulen la teoría-praxis del conocimiento pedagógico e (inter)disciplinar. En este sentido, las perspectivas de género juegan un papel fundamental en los contextos y procesos formativos, puesto que develan "la incardinación ideológica de sujetos y no sujetos", es decir, "el espacio real o imaginario" de sus prácticas discursivas, productos culturales, itinerarios socioprofesionales, ámbitos de acción 
y expectativas de futuro. Si estas concepciones intentan describir, interpretar y analizar cómo las condiciones materiales y simbólicas (re)producen las diferencias-semejanzas que distinguen "los sexos-cuerpos-sexualidades", y cuál es su impacto en las operaciones representacionales y experiencias identitarias de hombres y mujeres y de heterosexuales y homosexuales, entonces, por qué se podría invisibilizar este enfoque teórico-analítico en "el aprender a conocer, aprender a ser, aprender a hacer y aprender a vivir juntos/as de las futuras generaciones" (Freixas y Fuentes-Guerra 1994; Delors 2000; Tuozzo 2000; Hexagrama Consultores, FLACSO, IESCO 2006).

Asimismo, si se considera que los contextos socioeducativos, cada vez más complejos, diversos e interconectados, participan de "la discriminación, exclusión y reproducción de estereotipos sexistas, clasistas y étnicos". O si se reflexiona en los recientes y amplios estudios sobre violencia física, psíquica y moral hacia el/la otro/a distinto/a, "un hostigamiento sostenido en el tiempo que está legitimado por el mundo adulto y materializado por los/las niños/as y jóvenes en ciertas comunidades educativas". En estas situaciones es fundamental develar "las alianzas estratégicas entre sujetos y no sujetos", las complicidades entre los sexos-cuerpos-sexualidades que imparten y reciben estas humillaciones y su potencial violencia simbólica hacia "los/las anormales y/o discapacitados/as; los/las feos/as, gordos/as, morenos/as; los/las indígenas e inmigrantes; los/las pobres, cuicos/as o el/la flaite roto/a; los/las homosexuales, las mujeres, los niños y jóvenes afeminados, las niñas y jóvenes ahombradas, entre otros/as" (Irigoyen 1998; Hexagrama Consultores, FLACSO, IESCO 2006; Zerón 2006).

En este sentido, las últimas investigaciones advierten que la Formación Docente Inicial "no aborda con seriedad profesional" las problemáticas de género, ni "con suficiente profundidad" los procesos de construcción de las identidades y opciones sexuales. Como también, explicitan que los/las estudiantes de pedagogía poseen escasos conocimientos sobre desarrollo, anatomía y fisiología de los órganos sexuales primarios y secundarios, y que en el caso de las mujeres este desconocimiento es mayor. No obstante, se manifiesta que estos actores sociales han ido transformando sus estereotipos sexistas, persisten las asociaciones entre "la naturaleza biológico-psicológica del desarrollo sexual" con ciertos (pre)juicios hacia el ejercicio de la sexualidad masculina y femenina. Estos relevan la importancia de la virginidad y de la familia nuclear, procreadora y heterosexual; califican como situación dolorosa el primer coito femenino o "de desecho dañino" la sangre menstrual; e infieren las prácticas sexuales de las personas a partir de "datos secundarios, absurdos y superficiales". Es interesante observar cómo estas prácticas discursivas promueven "una ley simbólica en materia de sexos-cuerpos-sexualidades", que distancia "los lugares comunes de la aceptación (las aspiraciones, ideales y deseos de consumación de los/las sujetos) y los del rechazo potencial hacia los/las no sujetos". (Freixas y Fuentes-Guerra 1994; Vallejo, Rey y López 2001; UNESCO 2001; Hexagrama Consultores, FLACSO, IESCO 2006).

$\mathrm{Al}$ respecto, es sugerente analizar cómo las inequidades de género están presentes en las prácticas de enseñanza y procesos de aprendizaje sobre sexo, cuerpo y sexualidad masculina y femenina. Estas estrategias pedagógicas no impactan ni benefician de igual manera a hombres y mujeres, puesto que los primeros en comparación con las puntuaciones de las segundas presentan mayores conocimientos (saber-conocer), competencias (saber-hacer) y actitudes (saber-ser) en este ámbito. Frente a estas desigualdades, las justificaciones documentadas describen que la formación personal, académica, profe- 
sional y social de los/las futuros/as profesores/as "no aborda los aspectos relacionados con la sexualidad, o cuando los aborda son revisados con superficialidad o constituyen un fragmento descontextualizado dentro del programa formativo". Y las explicaciones más radicales señalan que estos contextos y procesos formativos "son intrínsecamente conservadores/as", puesto que "el deber ser-hacer-saber-decir de la profesión docente" se instala en "un pedestal inmutable" a los cambios generacionales e "imperturbable" ante las opciones, condiciones y prácticas sexuales de sus actores protagónicos/as (Cherryholmes 1999; Vallejo, Rey y López 2001; Talburt y Steinbert 2005; Matus 2006).

\section{MARCO TEORICO-ANALITICO DEL ESTUDIO}

Desde la década del setenta, los usos de la categoría de género intentan complejizar "las identificaciones-diferenciaciones históricas y socioculturales entre los sexos", las proximidades, similitudes y semejanzas que comparten los varones, las mujeres, y entre varones y mujeres, y las oposiciones, distinciones y discrepancias que los/las separan. Este enfoque teórico-analítico problematiza "el determinismo biológico y esencialismo psicológico" sobre la naturaleza, condición y propiedad de lo masculino y de lo femenino, "su lógica binaria y relación de complementariedad". Una matriz de control, sujeción y producción de "sujetos y no sujetos", que por una parte describe las categorías normativas, unidades significantes y dinámicas relacionales entre "los sexos-cuerpos-sexualidades", y por otra identifica los campos de (im)posibilidades de sus operaciones representacionales y experiencias identitarias (Scott 1990; Laurentis 1991; Chartier 1992; Lamas 1996, 1998; Martínez 2002).

Como construcción teórica, la lógica simbólica, normativa y económica del género (in)visibiliza los dispositivos de la sexualidad, con los que "sujetos y no sujetos" (re) significan sus espacios reales e imaginarios, ámbitos de acción y productos culturales. Estas prácticas discursivas develan los efectos materiales y simbólicos de la norma del sexo e imperativo heterosexual, cuya inteligibilidad cultural y legitimidad discursiva está "naturalmente adherida, justificada y tematizada en los cuerpos que importan", y en sus procesos de (re)construcción, adjudicación y empoderamiento. Por consiguiente, los dispositivos de la sexualidad califican-circunscriben, posicionan-demarcan y regulandiferencian a "los sexos-cuerpos fragmentados, incompletos e inestables", "imprimen su viabilidad en el mundo de la vida", brindándole claves de acceso y dinámicas de movimiento dentro de la cultura (Foucault 1976, 1981, 1987, 1997; Lamas 1996, 1998; Bourdieu 2000; Butler 2002).

Estos elementos discursivos y no discursivos descifran la naturaleza, penetran la existencia, tematizan la operatividad y justifican lo permitido, extremo e intermedio, en el campo del sexo-cuerpo-sexualidad. La producción "del nodo vibrante del género" define "un objetivo estratégico y su (re)construcción propiamente tal", estos procesos de "sobredeterminación funcional y saturación estratégica" originan consecuencias contradictorias y efectos inesperados, que demandan la acomodación de sus condiciones y contextos. De esta manera, "la naturaleza, existencia, operatividad y legitimidad de sujetos y no sujetos" implica una descripción genealógica, su constitución como "sujetos de conocimiento" o una ontología de sí mismo/a en relación con la verdad; como "sujetos que actúan sobre otros/as" o una ontología de sí mismo/a en relación con el poder; y como "sujetos 
éticos/as" o una ontología de sí mismo/a en relación con la moral. Esta descripción considera tres principios metodológicos: las condiciones de (re)producción y distribución de las prácticas discursivas, sus (dis)continuidades y especificidades enunciativas (su violencia potencial hacia las cosas) (Foucault 1981, 1987, 1997; Butler 2002; Castro 2004).

Desde esta perspectiva, las (re)significaciones sobre las formas del poder surgen "en la tensa relación entre las racionalidades de los Estados Modernos", una dominación étnica, social y religiosa entendida como explotación del individuo-separado del producto de su trabajo, o como sumisión del sujeto. La descripción genealógica se inserta en esta última, ya que las condiciones materiales y simbólicas de la Modernidad desintegran los procesos de constitución "de sujetos y no sujetos". Asimismo, las (re)significaciones sobre las formas del saber surgen "en la tensa relación entre las racionalidades de las disciplinas académicas", una problematización del Estado, los sistemas de diferenciación, criterios de rigor científico, enfoques, problemas, preguntas, objetivos y estrategias metodológicas de las ciencias (Foucault 1997; Zizek 2001; Butler 2002; Castro 2004)

"En la sociedad de normalización", las nociones de verdad, poder y moral de "sujetos y no sujetos" describen la norma del sexo e imperativo heterosexual. La descripción genealógica de estas prácticas discursivas (re)significa el poder-saber, tanto en sus formas externas, extremas y sutiles, como en sus técnicas históricas, concretas y efectivas. Esta producción positiva, (dis)continua y específica devela los instrumentos-mecanismos de control-vigilancia y los de subordinación-docilización ante "los sexos-cuerpos-sexualidades (re)construidos para sí mismos/as".

Como categoría analítica, la lógica simbólica, normativa y económica del género (in) visibiliza las tecnologías del poder/saber productivo, con las que "sujetos y no sujetos" estructuran las operaciones representacionales asociadas a las relaciones de género y las experiencias identitarias relativas a la diferencia-semejanza sexual. Al respecto, Butler (2002: 36) señala: “... esta morfología (real o imaginaria)... se trata de una operación orquestada mediante esquemas reguladores que producen posibilidades inteligibles y morfológicas...". De este modo, los procesos de objetivación develan los campos de (im) posibilidades de "sujetos y no sujetos", "sus explicaciones de sentido común" permiten conocer las claves, accesos, dinámicas y movimientos dentro de la inteligibilidad cultural y legitimidad discursiva. Esta producción describe los modelos explicativos sobre los modos de ser-hacer-saber-decir, cuyas estrategias de poder y tácticas de saber cristalizantransparentan-legitiman los conocimientos, competencias y actitudes específicas. Así, las operaciones representacionales o las explicaciones objetivadas, elaboradas y compartidas expresan una relación epistemológica, axiológica, ontológica y ética entre sujetos-subjetivados, entre objetos-objetivados y entre sujetos-objetos. Estas operaciones sustituyen "algo en la (in)conciencia de alguien", ciertos procesos de subjetivación donde "sujetos y no sujetos" lo incorporan como unidades de sentido. Estas imágenes-apariencias-reacciones de sí mismo/a califican-circunscriben, posicionan-demarcan y regulan-diferencian "el carácter significante y performativo de la experiencia identitaria". La constitución simbólica, autónoma y creativa de "los sexos-cuerpos-sexualidades que importan", en tanto "sistematiza sus imperativos, reitera sus actuaciones y replica sus fenómenos" (Moscovici 1986; Jodelet 1989; Laurentis 1991; Chartier 1992).

Desde esta perspectiva, las tecnologías del poder-saber productivo se fusionan estratégicamente en la división sexual del trabajo. Estas categorías normativas, unidades significantes y dinámicas relacionales distribuyen "los sexos-cuerpos-sexualidades" como "bienes y 
capitales simbólicos", y regulan sus intercambios en los "espacios reales e imaginarios". En este sentido, los intercambios simbólicos describen los esquemas de percepción asociados a las relaciones de género, "un mapeo sobre los territorios y dominios de control-vigilancia"; y muestran las experiencias de apropiación relativas a la diferencia-semejanza sexual, "una visibilización sobre las incardinaciones de la subordinación-docilización". De esta forma, cuando "sujetos y no sujetos" aplican sus esquemas de percepción y experiencias de apropiación "a lo que les controla-subordina", inevitablemente estas prácticas discursivas serán un instrumento-mecanismo de (re)conocimiento entre los/las mismos/as. Esta violencia simbólica "naturaliza las asimetrías entre dominadores/as y dominados/as", cuyas (in)decisiones (in)conscientes, (des)controles (in)voluntarios y/o concesiones obligatorias están "simbolizadas, normalizadas y economizadas en las superficies y profundidades de sus sexos-cuerpos-sexualidades" (Foucault 1992; Bourdieu 2000; Butler 2002).

Igualmente, la división sexual del trabajo configura los campos de (re)producción "de los bienes y capitales simbólicos", siendo su ejemplo por excelencia el mercado matrimonial y las relaciones de parentesco. Al respecto, se entiende que "los derechos y deberes de los varones" definen el estatus, el rol y las funciones de las mujeres, éstas como objetos de intercambio e instrumentos de reproducción acrecientan, distribuyen o perpetúan el honor, valor y prestigio social de éstos. Asimismo, "los derechos y deberes de los/las heterosexuales" definen el estatus, el rol y las funciones de los/las homosexuales, "los bienes y capitales de la heterosexualidad" (re)producen los sentidos y valores asociados a la homosexualidad, y los distribuyen en sus contextos, relaciones y experiencias. Por lo tanto, si los campos de (re)producción suponen una alianza estratégica y/o comunicación equivalente "entre sujetos" (los varones y los/las heterosexuales), su consecuencia es la institucionalización de la violencia simbólica "hacia los/las no sujetos" (las mujeres y los/las homosexuales). Esta dominación masculina e imperativo heterosexual niega "la constitución de sujetos de derechos y deberes" a estos/as últimos/as, puesto que al estar desprovistos/as de "los bienes y capitales simbólicos" no pueden operar en "su mercado de alianzas e intercambios" (Foucault 1992; Bourdieu 2000; Butler 2002).

Asimismo, las estrategias del poder y tácticas del saber configuran las tecnologías del biopoder, ciertas intervenciones políticas que regulan la vida y la muerte de "sujetos y no sujetos". Desde el siglo XVII, éstas se organizan en torno a las disciplinas académicas y conciben el cuerpo anatómico como "máquina humana". A mediados del siglo XVIII, "la sociedad de normalización" constituye una biopolítica de la población, donde el cuerpo-especie surge como soporte de los procesos biológicos y sociológicos de las masas humanas (el eje que articula el desarrollo del capitalismo). En este sentido, las intervenciones biopolíticas controlan-vigilan "los sexos-cuerpos-sexualidades como problemas y fenómenos poblacionales", por lo que estiman sus equilibrios y probabilidades estadísticas de larga duración. Y las intervenciones disciplinarias subordinan-docilizan "el sexo-cuerpo-sexualidad como individualidad útil y (re)productiva", por lo que describen sus mecanizaciones, adiestramientos y normalizaciones. De esta forma, las tecnologías biopolíticas y disciplinarias califican-circunscriben, posicionan-demarcan y regulan-diferencian el cuerpo-especie y el cuerpo-máquina, donde la regulación poblacional obtiene sus efectos en el nivel de la disciplina, esto es, en los procesos de sexualización de la infancia e histerización del cuerpo de la mujer. Y la regulación disciplinaria obtiene sus efectos en el nivel de la población, es decir, en el control de la natalidad y psiquiatrización de las perversiones (Foucault 1976, 1992, 1997; Castro 2004). 
"En la sociedad de normalización”, las operaciones representacionales y experiencias identitarias de "sujetos y no sujetos" condicionan las identificaciones-diferenciaciones con ciertas opciones, condiciones y prácticas sexuales. Los procesos de objetivaciónexternalización y los de subjetivación-internalización mantienen "una alianza estratégica con el imperativo heterosexual" y "una complicidad con la norma del sexo", cuyas actuaciones performativas, reiterativas y sistemáticas cristalizan-transparentan-legitiman "los fenómenos que nombra".

Consiguientemente, la lógica simbólica, normativa y económica del género se entiende como una matriz de control, sujeción y producción “de sujetos y no sujetos". Una construcción teórica de los dispositivos de la sexualidad y una construcción analítica de las tecnologías del poder/saber productivo, que describen las categorías normativas, unidades significantes y dinámicas relacionales entre "los sexos-cuerpos-sexualidades", e identifican los campos de (im)posibilidades de sus operaciones representacionales y experiencias identitarias. En este sentido, los modelos explicativos sobre los modos de ser-hacer-saber-decir y las unidades de sentido de las imágenes-apariencias-reacciones de sí mismo/a visibilizan la materialización simbólica de "sujeto y no sujetos". Los efectos materiales y simbólicos de la sociedad de normalización, en tanto, "inteligibilidad cultural y legitimidad discursiva de los sexos-cuerpos-sexualidades que importan”.

Por lo tanto, la pregunta de investigación: ¿cuáles son las operaciones representacionales y experiencias identitarias sobre heterosexualidad y homosexualidad de los/las estudiantes de pedagogía, en los contextos de Formación Docente Inicial? intenta describir, interpretar y analizar quiénes son estos actores sociales y cómo (re)construyen estas prácticas discursivas en los contextos y procesos formativos. En este sentido, las propuestas nacionales e internacionales sobre Formación Docente Inicial entienden "al docente como un/a profesional de la educación", sin embargo persiste una relación invisibilizada entre esta disciplina académica y las perspectivas de género. Su articulación permitiría visibilizar la división sexual del trabajo, la violencia simbólica y "el currículo oculto de las discriminaciones" en las instituciones formadoras de docentes. Como también permitiría develar los dispositivos de la sexualidad y las tecnologías del poder-saber productivo en la formación personal, académica, profesional y social de los/las futuros/as profesores/as, cuyas nociones de verdad, poder y moral articulan "los (pre)juicios sexistas, clasistas y éticos" en sus prácticas de enseñanza y procesos de aprendizaje.

Para una mayor comprensión del enfoque teórico-analítico del estudio, se presenta el siguiente mapa conceptual (figura 1):

\section{MARCO METODOLOGICO DEL ESTUDIO}

Este estudio asumió el enfoque cualitativo de investigación, que supone la inmersión del investigador/a en las condiciones, contextos y procesos institucionales, a fin de comprender las prácticas discursivas de sus actores sociales. El paradigma interpretativo devela "la incardinación ideológica de sujetos y no sujetos", una categorización de sus procesos de objetivación/subjetivación y una sistematización de sus tramas culturales de significación. Al respecto, la objetividad se refiere a la selección de la metodología, cuya confiabilidad y validez integra y/o confronta estos hallazgos de investigación con las distintas disciplinas académicas. Los procedimientos de confiabilidad y validez cau- 


\section{Figura 1}

Lógica simbólica, normativa y económica del género.

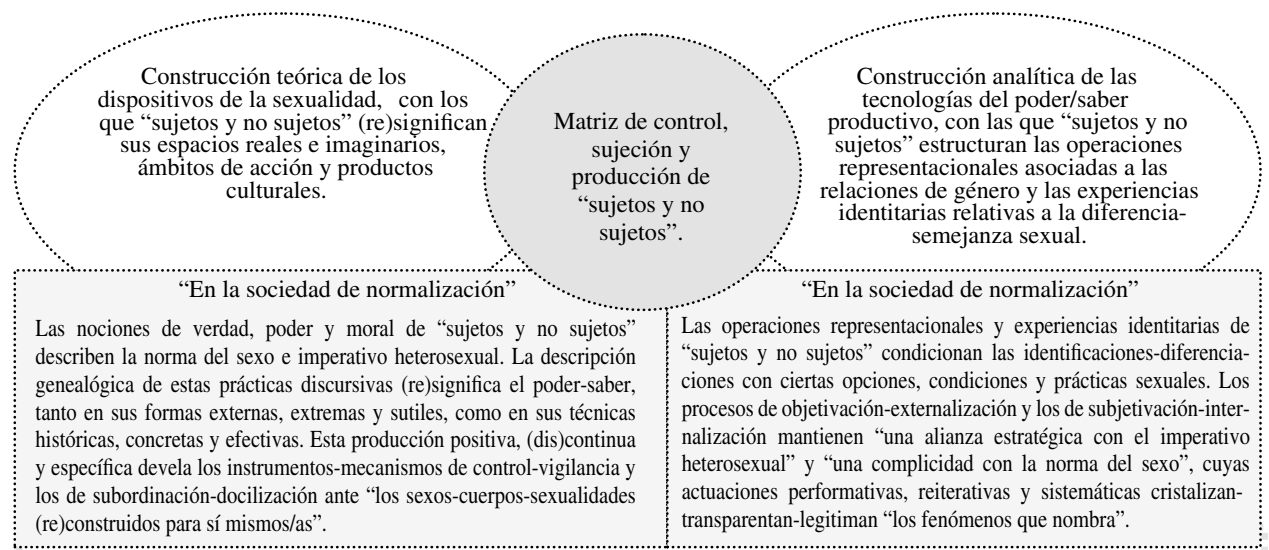

Dispositivos de la sexualidad - Tecnologías del poder-saber productivo

Describen las categorías normativas, unidades significantes y dinámicas relacionales entre "los sexos-cuerpos-

sexualidades", e identifican los campos de (im)posibilidades de sus operaciones representacionales y experiencias identitarias.

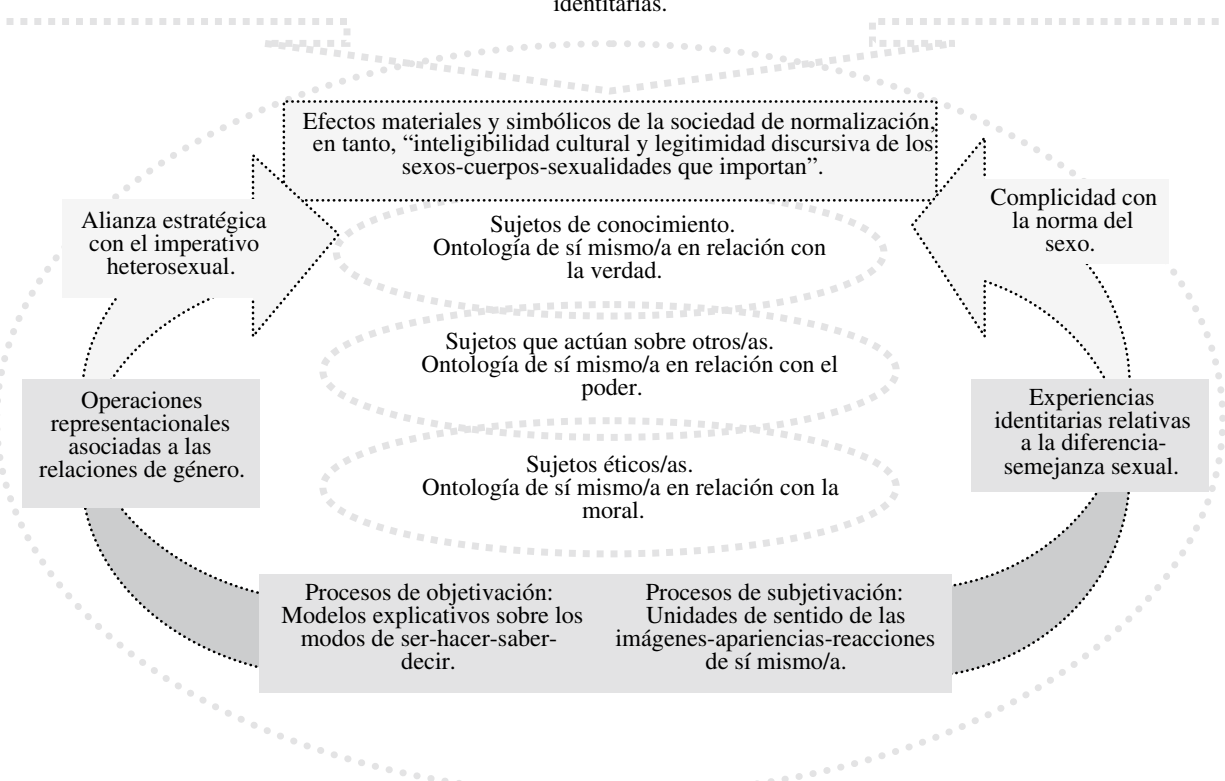

telan la consistencia de los procesos metodológicos y la interpretación de los productos alcanzados, independientemente de las circunstancias accidentales de la investigación. (De Gialdino 1992; Cárdenas 2001; Daniel 2002; Sandín 2003).

En este estudio se consideraron tres momentos metodológicos, con sus respectivos niveles de complejidad. La descripción analítica intentó rescatar las prácticas discursivas de varones y mujeres, los argumentos, posicionamientos y nominaciones explícitas 
y/o latentes que circunscriben "un sujeto-objeto en los espacios reales e imaginarios". La interpretación analítica procuró establecer relaciones de contingencia, asociación u oposición entre los modelos explicativos sobre los modos de ser-hacer-saber-decir y las unidades de sentidos de las imágenes-apariencias-reacciones de sí mismo/a. Las subcategorías semánticas diferenciaron las operaciones representacionales asociadas a las relaciones de género y las experiencias identitarias relativas a la diferencia-semejanza sexual. Finalmente, la triangulación teórico-analítica intentó relacionar estas prácticas discursivas con la lógica simbólica, normativa y económica del género (Cárdenas 2001; Sandín 2003).

Los/las sujetos del estudio son cinco varones y ocho mujeres insertos/as en el último año de la carrera de educación básica. El escenario de la investigación es una universidad tradicional chilena de la Región Metropolitana, adscrita al Consejo de Rectores. Esta institución de educación superior participó en el Programa de Fortalecimiento de la Formación Inicial Docente, está acreditada institucionalmente por la Comisión de Acreditación de Pregrado y cuenta con una trayectoria en la formación de profesores/as.

La estrategia de recolección del material de investigación fue el Foro de Discusión, una situación comunicativa de producción discursiva que visibiliza la organización sistémica y comunicación intersubjetiva de un grupo-curso. Estos vínculos afectivos y contenidos ideológicos mediatizan las relaciones entre los contextos institucionales y socioculturales. Por su parte, la estrategia de análisis del material de investigación fue el Análisis Crítico del Discurso Textual, ACDT, que articula la dimensión pragmática de la producción textual, con la dimensión semántica de sus productos socioculturales. Ambas estrategias permitieron develar las representaciones sociales sobre heterosexualidad y homosexualidad de los/las estudiantes de pedagogía, en los contextos de Formación Docente Inicial (Piña 1988; Bernard 1997; Neri 1997; Wodak y Meyer 2003).

- Descripción e interpretación teórico-analítica de los hallazgos de investigación.

- Representaciones sociales de LOS estudiantes de pedagogía sobre heterosexualidadhomosexualidad.

Parámetros de (in)discreción constituyen una ley material y simbólica, que condiciona y cualifica el comportamiento de homosexuales y heterosexuales. Los estudiantes de pedagogía entienden la (in)discreción como una "ley", que norma las condiciones y cualidades constantes e invariables del comportamiento homosexual y heterosexual. Una norma heterosexual como suprema autoridad del bien común, cuyos preceptos mandan, sancionan o prohíben el ejercicio de la homosexualidad. En este sentido, la ley material y simbólica describe las diferencias-semejanzas entre "la comunidad heterosexual", es decir, los contextos y relaciones socioculturales, y "la comunidad homosexual", esto es, el contexto cercano y las relaciones directas de los/las homosexuales. Por lo tanto, los estudiantes de pedagogía visibilizan una ley heterosexual que condiciona y cualifica los contextos y relaciones indiscretas de los/las homosexuales. 


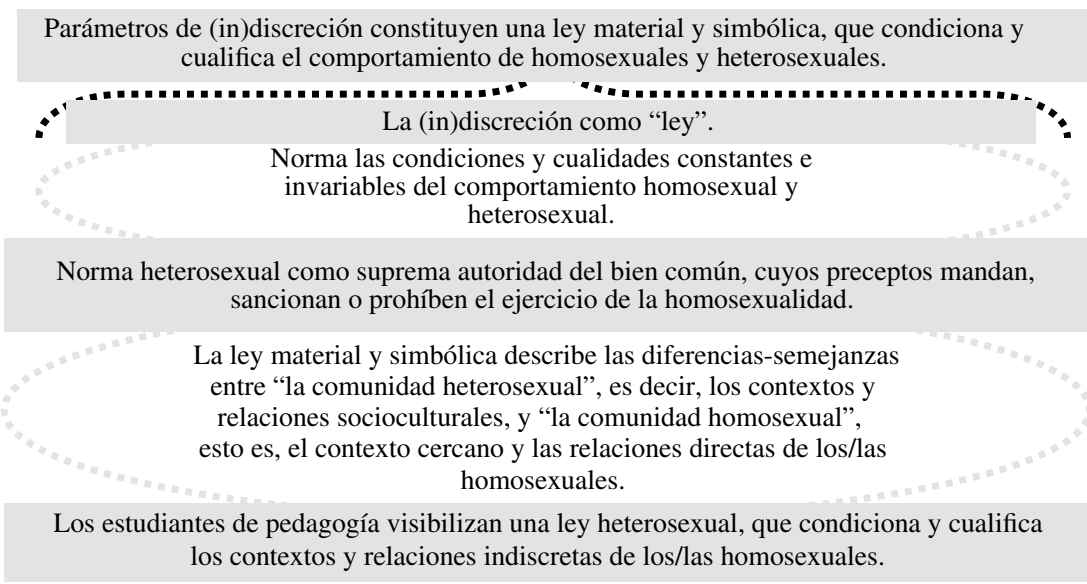

Homosexuales y heterosexuales serán aceptados/as por su comunidad siempre y cuando "sean discretos/as". Los estudiantes de pedagogía conciben los parámetros de (in)discreción como una medida de protección de la privacidad y una condición de participación en el conjunto social, puesto que "el ejercicio de la sexualidad requiere resguardarse de los (pre)juicios y observaciones del otro/a". Al respecto, las prácticas sexuales de los/las homosexuales "deben pasar inadvertidas", ya que sus demostraciones públicas de cariño y afecto constituyen una amenaza para los/las heterosexuales, cuyos (pre)juicios y observaciones las valoran como "conductas inadecuadas, anormales y desagradables". Por lo tanto, los estudiantes de pedagogía perciben que los/las homosexuales y heterosexuales mantienen los mismos parámetros de (in)discreción, "una opción de decir y elegir" según los niveles de apertura y aceptación de "la comunidad".

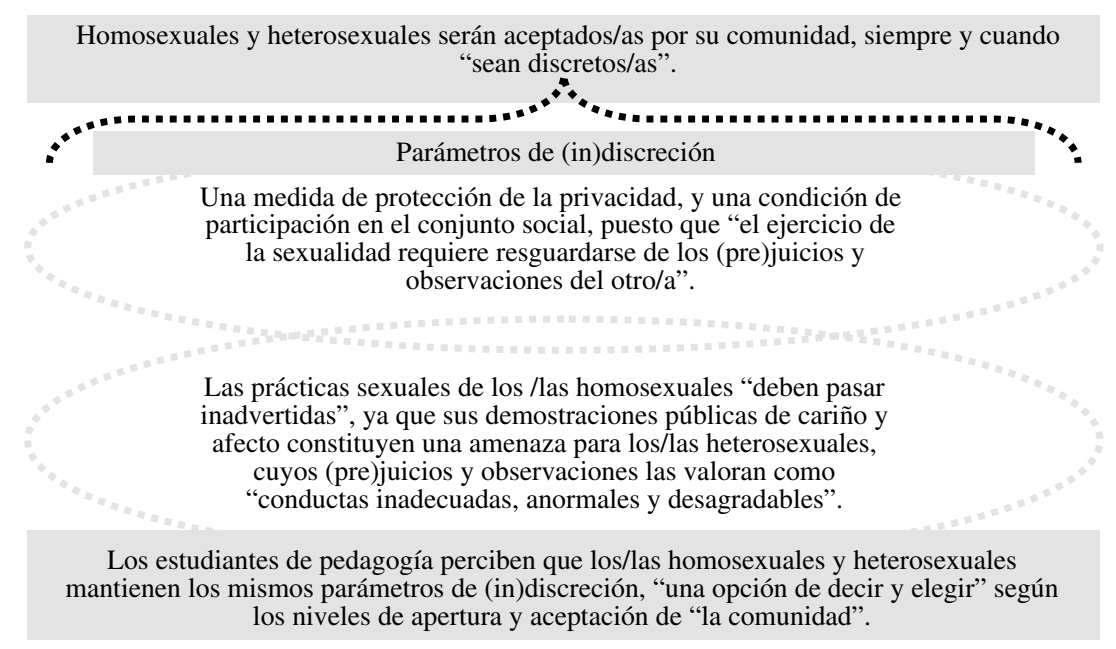


Demostraciones públicas de cariño y afecto entre homosexuales generan una situación "difícil y chocante" para los/las heterosexuales, por ello "nuestra sociedad las sanciona, prohíbe e (in)visibiliza". Los estudiantes de pedagogía entienden que esta situación "difícil y chocante" indispone y enfada a los/las heterosexuales. En este sentido, el encuentro violento con "el escenario extraño y ajeno de la homosexualidad" necesita de una preparación personal y social para conocerla, comprenderla y aceptarla. Al respecto, "nuestra sociedad sanciona, prohíbe e invisibiliza" las demostraciones de cariño y afecto de las parejas homosexuales, un asunto personal que describe la necesidad de conocer, comprender y aceptar la legitimidad de las opciones, condiciones y prácticas homosexuales, y un asunto social que muestra la necesidad de desarticular la hegemonía y los (pre) juicios de la heterosexualidad. Por lo tanto, los estudiantes de pedagogía observan las condiciones materiales y simbólicas que sancionan, prohíben e invisibilizan las prácticas sexuales de los/las homosexuales, una necesidad personal, académica, profesional y social como futuros profesores.

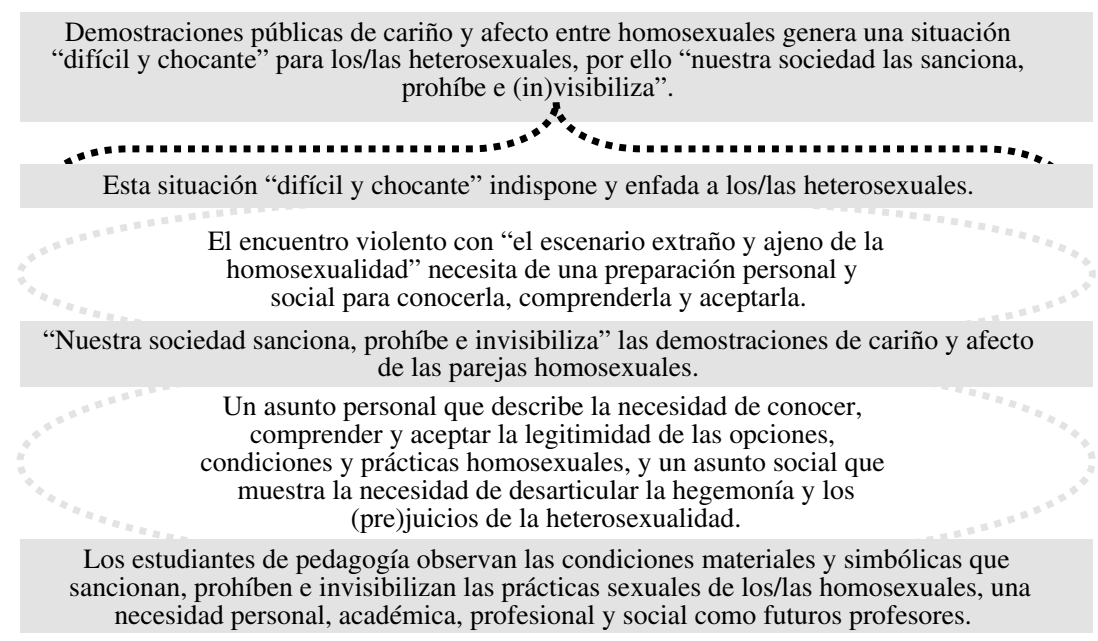

Demostraciones públicas de cariño y afecto entre homosexuales: visibilizan el rechazo, resistencias y falta de preparación de los/las heterosexuales. Los estudiantes de pedagogía manifiestan que el rechazo hacia la homosexualidad se ampara "en el principio universal de la heterosexualidad", una cualidad de derecho natural que discierne sobre el sentido ético-moral de las prácticas sexuales. Asimismo, la "naturaleza" de los/las heterosexuales circunscribe los sentidos, valores y fuerzas (des)proporcionadas de los/las homosexuales. Por lo tanto, los estudiantes de pedagogía visibilizan la "naturaleza" del rechazo, resistencia y falta de preparación hacia la homosexualidad, cuyas propiedades y características le otorgan una condición de desigualdad ante la heterosexualidad. 


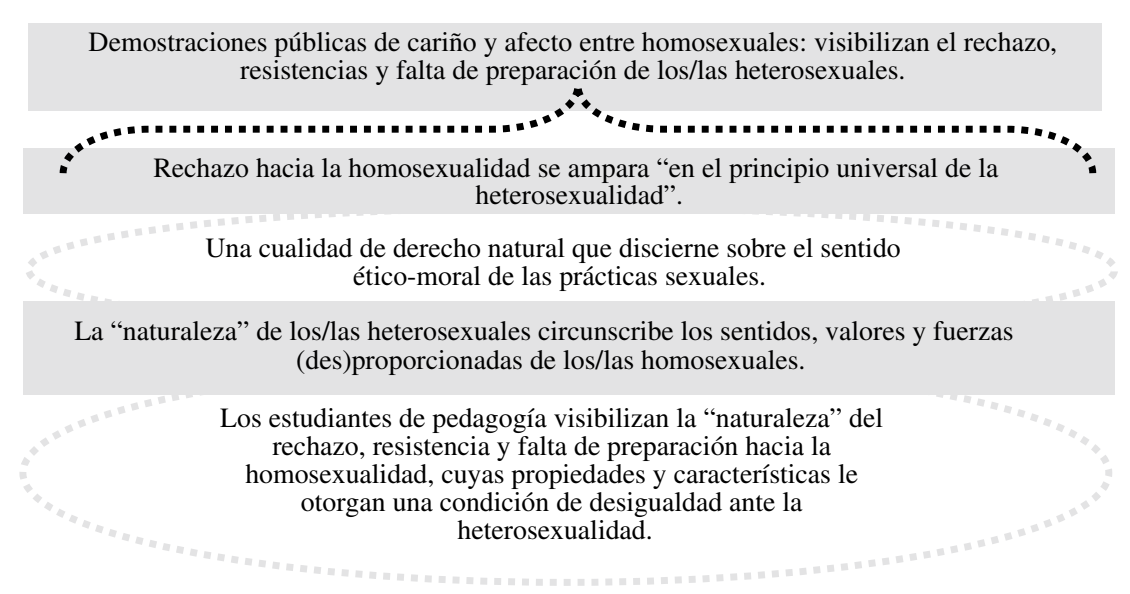

- Representaciones sociales de LAS estudiantes de pedagogía sobre heterosexualidadhomosexualidad.

Parámetros de (in)discreción para las parejas homosexuales y heterosexuales: identifican una prohibición a la exhibición pública de sus caricias y afectos. Las estudiantes de pedagogía manifiestan que los parámetros de (in)discreción constituyen "una variable asociada" al valor y sentido de una conducta (in)adecuada en el espacio público y privado, que identifica los niveles de prudencia, moderación y cautela de los/las homosexuales y heterosexuales, y sus grados de tolerancia e "(in)sensatez en el juicio". De esta manera, la "conducta discreta" describe la capacidad para identificar los límites materiales y simbólicos entre lo público y privado. En cambio, la conducta indiscreta describe la incapacidad para identificarlos. En este sentido, las parejas homosexuales y heterosexuales mantienen los mismos parámetros de (in)discreción, "una situación de contexto" e "(in)sensatez en el juicio" que controla-vigila y subordina-dociliza sus conductas públicas y privadas. Por lo tanto, las estudiantes de pedagogía visibilizan sus grados de tolerancia cuando describen las conductas (in)discretas de las parejas homosexuales y heterosexuales, una "(in)sensatez en el juicio" que prohíbe la exhibición pública de caricias y afectos. 


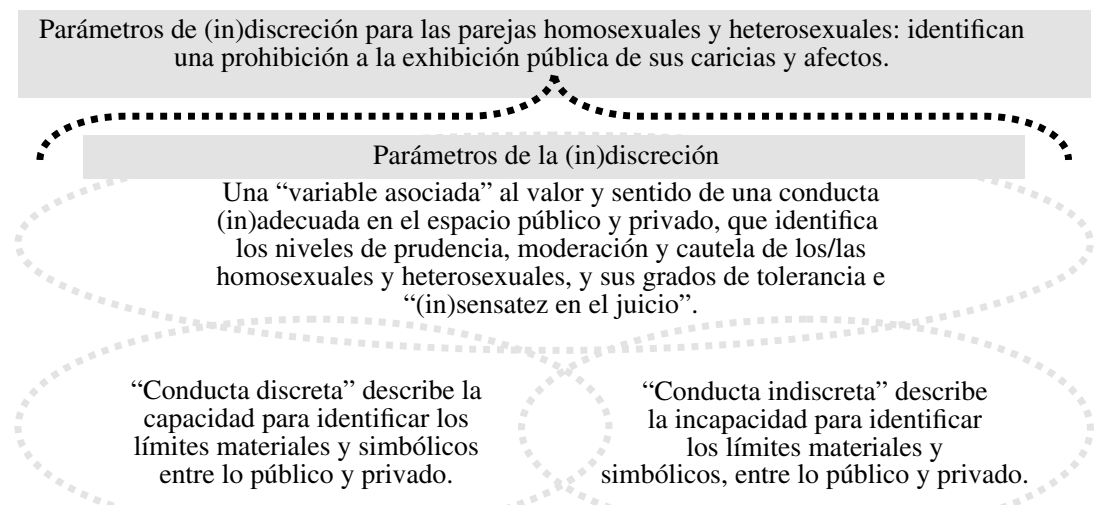

Las parejas homosexuales y heterosexuales mantienen los mismos parámetros de (in)discreción, "una situación de contexto" e "(in)sensatez en el juicio" que controla-vigila y subordina-dociliza sus conductas públicas y privadas.

y subordina-dociliza sus conductas públicas y privadas.
Las estudiantes de pedagogía visibilizan sus grados de
tolerancia cuando describen las conductas (in)discretas de las
parejas homosexuales y heterosexuales, una "(in)sensatez en
el juicio" que prohíbe la exhibición pública de caricias y
afectos.

(In)discreción de los/las homosexuales queda inscrita en los patrones culturales heterosexuales, que caracterizan "el comportamiento aceptable" de la pareja. Las estudiantes de pedagogía señalan que los parámetros culturales heterosexuales, es decir, las relaciones eróticas entre individuos de diferente sexo configuran "el comportamiento aceptable y discreto" de las parejas homosexuales, esto es, de las relaciones eróticas entre individuos del mismo sexo. En este sentido, el orden de superioridad de la heterosexualidad instala y legitima la inferioridad de la homosexualidad, sus niveles de dependencia y subordinación. Por lo tanto, las estudiantes de pedagogía como observadoras heterosexuales valoran "lo (in)aceptado e (in)discreto" del actuar en pareja. Un orden hegemónico que controla-vigila las relaciones de género, y subordina-dociliza "las posibles transgresiones de las otras condiciones, opciones y prácticas sexuales".

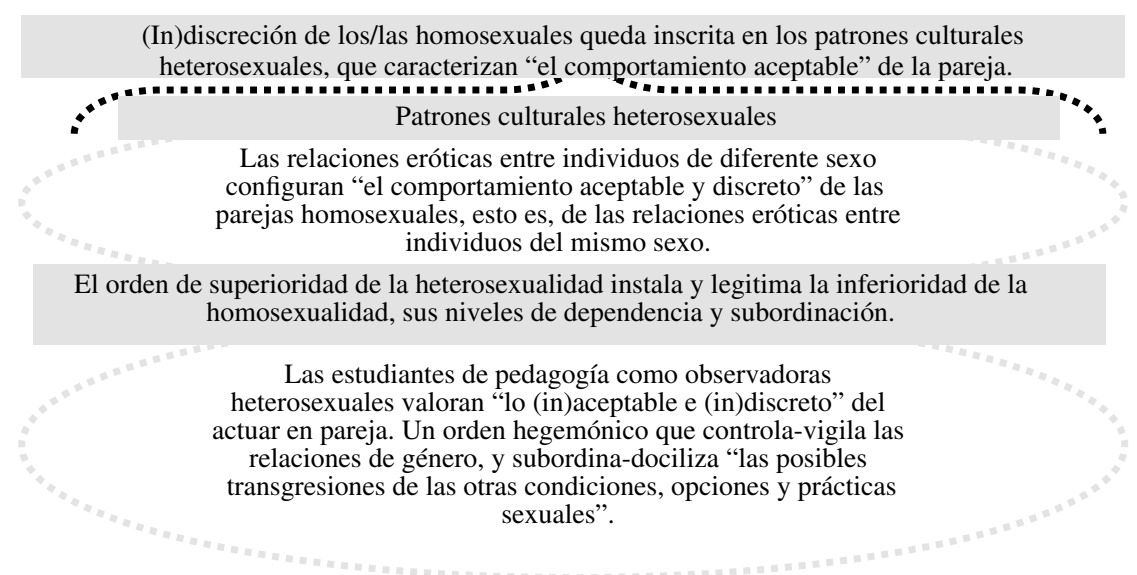


Las estudiantes de pedagogía "conservadoras" manifiestan una negación hacia los/las homosexuales: el reflejo de una incapacidad física y de una resistencia cultural hacia la diversidad sexual. Las estudiantes de pedagogía "conservadoras" favorecen la continuidad de los patrones culturales heterosexuales. Al respecto, la norma del sexo e imperativo heterosexual establece las formas de vida individuales y colectivas de "sujetos y no sujetos", develando una aversión hacia los comportamientos sexuales distintos o hacia los cambios radicales en el ejercicio de la sexualidad. De este modo, el rechazo muestra la oposición y desprecio hacia la homosexualidad, una "norma biológica heterosexual" que visibiliza las irregularidades e inestabilidades de la homosexualidad, y "una norma cultural heterosexual" que (in)visibiliza las resistencias y desaprobaciones hacia los/las homosexuales. Así, la diversidad sexual describe una (in)capacidad para comprender la hegemonía de la heterosexualidad, una voluntad para aceptar, respetar y/o tolerar las múltiples opciones, condiciones y prácticas sexuales. Por lo tanto, las estudiantes de pedagogía "conservadoras" visibilizan una incapacidad para comprender los patrones culturales heterosexuales; una imposibilidad para aceptar, respetar y/o tolerar la diversidad sexual; y las limitaciones y uniformidades en la formación personal, académica, profesional y social como futuras profesoras.

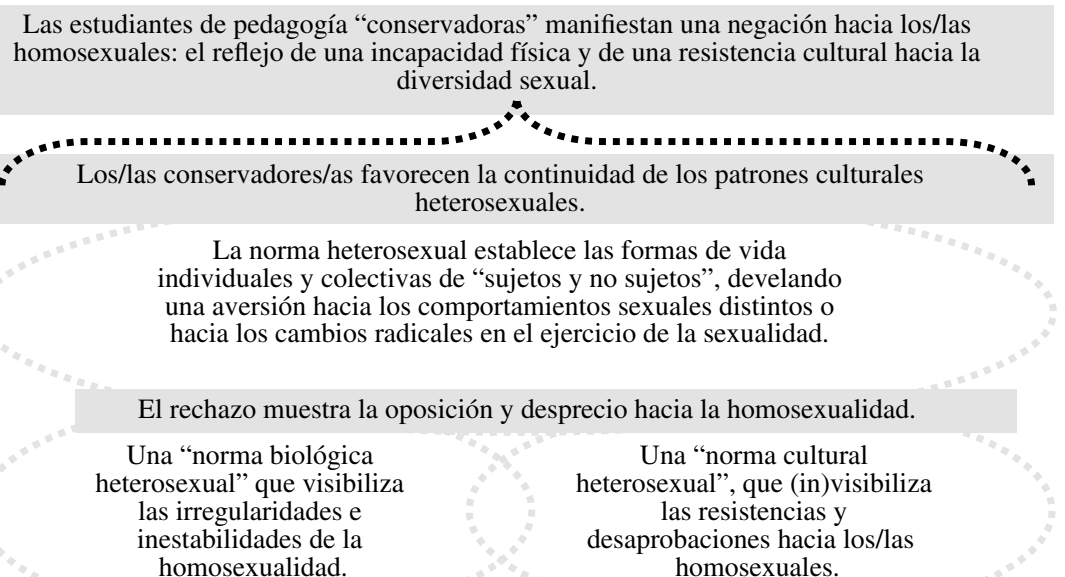

La diversidad sexual describe una (in)capacidad para comprender la hegemonía de la heterosexualidad, una voluntad para aceptar, respetar y/o tolerar las múltiples opciones, condiciones y prácticas sexuales.

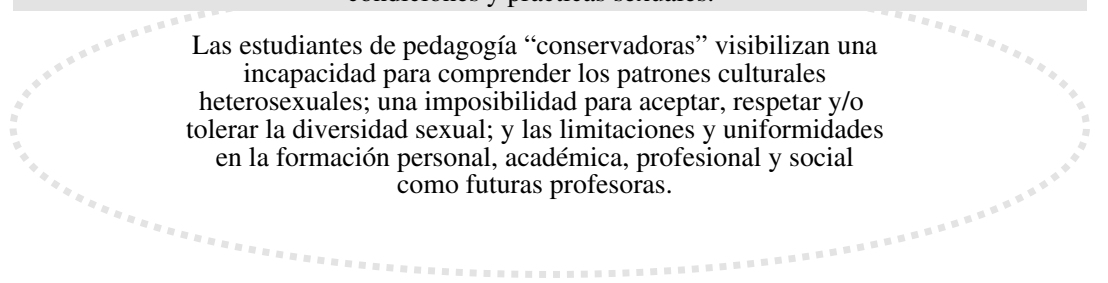

Las estudiantes "homofóbicas" visibilizan una aversión hacia la exposición pública de "los sexos-cuerpos-sexualidades homosexuales". Las estudiantes de pedagogía "homofóbicas" demarcan las disposiciones y oposiciones entre heterosexuales y homosexuales, un 
procedimiento selectivo consistente que muestra las competencias materiales y simbólicas del primero y la subordinación y repugnancia hacia el segundo. Aunque estas prácticas discursivas relevan el derecho a la heterosexualidad y homosexualidad, es decir, una facultad para elegir y ejercer libremente una opción sexual, persisten las contradicciones, adversidades y resistencias ante la opción homosexual, que "sin ningún problema" impugna sus cuerpos y actos. Por lo tanto, las estudiantes de pedagogía "homofóbicas" valoran como desagradable las demostraciones públicas de cariño y afecto de los/las homosexuales, una impresión que niegan su condición de persona y su capacidad para entregar sentimientos de amor.

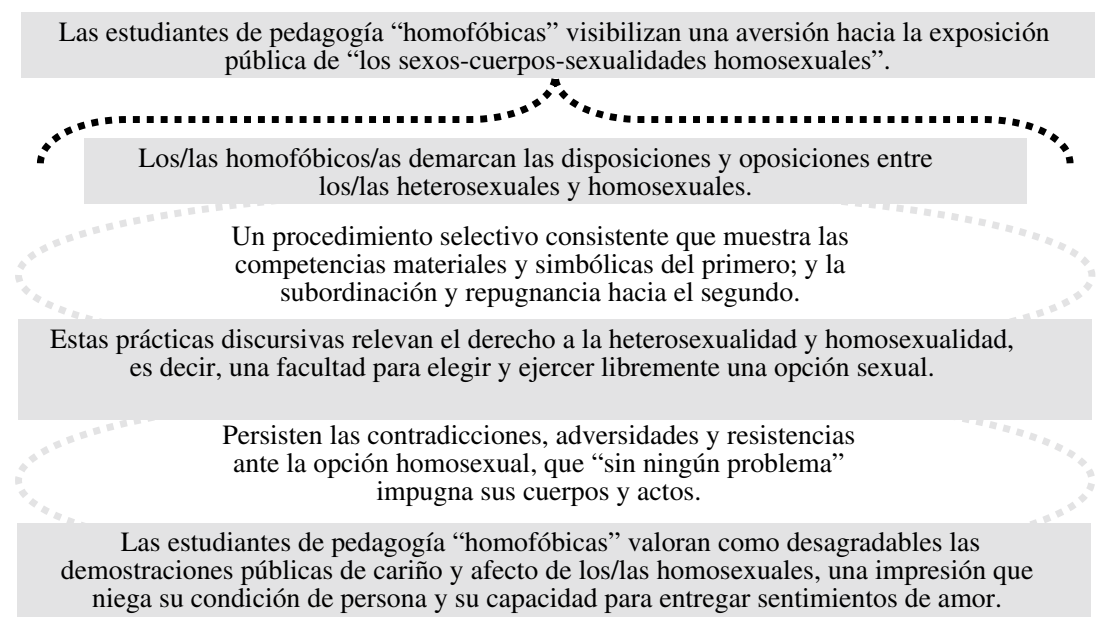

\section{TRIANGULACION TEORICO-ANALITICA DE LOS HALLAZGOS DE INVESTIGACION}

La lógica simbólica, normativa y económica del género permite comprender los conocimientos (saber conocer), las competencias (saber hacer) y las actitudes (saber ser) que se tematizan a partir de la "diferencia-semejanza sexual", que develan las condiciones históricas y socioculturales y los intereses ideológicos de las distintas áreas disciplinares. Al respecto, la "diferencia-semejanza sexual" se entiende como una (re)interpretación performativa de "la norma del sexo y del imperativo heterosexual". Una posición narrativa dirigida hacia los/las otros/as, cuyos modelos explicativos sobre los modos de ser-hacer-saber-decir (re)significan los dispositivos de la sexualidad y las tecnologías del poder-saber productivo. Y una posición narrativa dirigida hacia sí mismo/a, cuyas unidades de sentidos de las imágenes-apariencias-reacciones del sexo-cuerpo-sexualidad traspasan su materialidad biológica y se constituyen en existencia psíquica. Por lo tanto, las identidades sexuales y las de género son procesos dinámicos de resistencia y/o (des) apropiación, estas actuaciones performativas, reiterativas y sistemáticas cristalizan-transparentan-legitiman "los fenómenos que nombra". (Foucault 1981, 1987, 1997; Gasque 1990; Torres 1992; Lamas 1996, 1998; Butler 2002). 
Desde la discusión teórica del psicoanálisis, las identidades sexuales son configuraciones de segundo orden, una estructuración psíquica ante la castración-posesión simbólica (los posicionamientos simbólicos, normativos y económicos ante el falo); y una articulación imaginaria ante la (re)solución del drama edípico (los posicionamientos simbólicos, normativos y económicos ante las figuras parentales). Esta producción es positiva, (dis) continua y específica, puesto que sus configuraciones son autónomas y anteriores a las opciones, condiciones y prácticas sexuales de "sujetos y no sujetos". Por consiguiente, los modelos explicativos sobre los modos de ser-hacer-saber-decir y las unidades de sentido de las imágenes-apariencias-reacciones de sí mismo/a son permeables a los cambios, dado que se distancian de los determinismos biológico-psicológicos, (des)entrañan los nudos problemáticos de la "diferencia-semejanza sexual", y se (des)marcan de los posicionamientos ante la heterosexualidad y homosexualidad (Foucault 1981, 1987, 1997; Gasque 1990; Torres 1992; Lamas 1996, 1998; Curiel 2004; Butler 2002).

Asimismo, las identidades de género son distinciones de tercer orden, las condiciones materiales y simbólicas circunscriben los espacios reales o imaginarios, ámbitos de acción y productos culturales de la feminidad y masculinidad, de la heterosexualidad y homosexualidad. Estas identidades (re)significan las imágenes-apariencias-reacciones de sí mismo/a a partir de la "diferencia-semejanza sexual", materializan "los sexos-cuerpossexualidades de sujetos y no sujetos" y condicionan histórica y socioculturalmente la división sexual del trabajo. Estas nociones de verdad, poder y moral se constituyen en coexistencia, reciprocidad y retroalimentación, sus configuraciones reales o imaginarias conceden información privilegiada y específica de las mismas, tanto en la creación significativa de sí mismo/a como en la creación significativa del "otro/a". Por lo tanto, las representaciones sociales sobre heterosexualidad y homosexualidad de los/las estudiantes de pedagogía, en los contextos de Formación Docente Inicial, intentan describir, interpretar y analizar quiénes son estos actores sociales y cómo (re)construyen estas prácticas discursivas en los contextos y procesos formativos (Foucault 1981, 1987, 1997; Gasque 1990; Torres 1992; Lamas 1996, 1998; Espinosa 2003; Butler 2002).

Los estudiantes de pedagogía describen los parámetros de (in)discreción como una ley material y simbólica que condiciona y cualifica los comportamientos de homosexuales y heterosexuales, "los/las que serán aceptados/as por su comunidad siempre y cuando sean discretos/as". Es sugerente analizar cómo estos actores sociales mantienen "una complicidad con la norma del sexo y una alianza estratégica con el imperativo heterosexual", puesto que los esquemas de percepción y las experiencias de apropiación de los/ las sujetos controlan-vigilan y subordinan-docilizan los comportamientos (in)adecuados "de los/las no sujetos". En este sentido, "la comunidad heterosexual acepta o rechaza" a los/las homosexuales siempre y cuando sean respetuosos/as de "su autoridad suprema sobre el bien común". De este modo, los contextos constantes y relaciones invariantes de los/las heterosexuales fiscalizan los contextos inconstantes y relaciones variantes de los/ las homosexuales, parámetros de (in)discreción que varían según los niveles de aperturatolerancia y aceptación-respeto de los primeros.

Igualmente, "nuestra sociedad sanciona, prohíbe e (in)visibiliza" las demostraciones públicas de cariño y afecto entre "no sujetos" porque generan una situación "difícil y chocante para los/las sujetos". De la misma forma, las demostraciones públicas entre homosexuales reflejan el rechazo, resistencia y falta de preparación de los/las heterosexuales. Es interesante observar cómo "las conductas inadecuadas y desagradables de los/las no 
sujetos" se constituyen en una situación amenazante para "los/las sujetos". De este modo, la discriminación hacia los/las homosexuales ampara la lógica simbólica, normativa y económica de la heterosexualidad, cuyas nociones de verdad, poder y moral controlanvigilan las otras opciones, condiciones y prácticas sexuales, y subordinan-docilizan "la naturaleza biológica y (re)productiva de los sexos-cuerpos-sexualidades".

Las estudiantes de pedagogía identifican los parámetros de (in)discreción para las parejas homosexuales y heterosexuales, una prohibición a la exhibición pública de sus caricias y afectos. Sin embargo, "la (in)discreción de los/las no sujetos" queda inscrita en los patrones culturales de los/las sujetos, quienes caracterizan "el comportamiento aceptable" de la pareja. Es sugerente analizar cómo las futuras profesoras describen las conductas (in)discretas de heterosexuales y homosexuales, "una (in)capacidad e (in)sensatez en el juicio" para identificar los límites materiales y simbólicos entre lo público y privado. De esta manera, "el mundo público de la heterosexualidad y el mundo privado de la homosexualidad" estructuran las operaciones representacionales asociadas a las relaciones de género y las experiencias identitarias relativas a la "diferencia-semejanza sexual". Estos modelos explicativos sobre los modos de ser-hacer-saber-decir de "sujetos y no sujetos" califican-circunscriben, posicionan-demarcan y regulan-diferencian las unidades de sentido de las imágenes-apariencias-reacciones sobre sí mismos/as.

Asimismo, las estudiantes de pedagogía "conservadoras" manifiestan una negación hacia los/las homosexuales, el reflejo de una incapacidad física y de una resistencia cultural hacia la diversidad sexual. De este modo, la heterosexualidad como una normalización biológica "naturaliza las irregularidades, anomalías y patologías de la homosexualidad", y como normalización sociocultural "naturaliza las discriminaciones y exclusiones hacia los/las homosexuales". En la sociedad de normalización, los/las heterosexuales como sujetos de derechos y deberes ciudadanos son los/las encargados/as de aceptar o rechazar "las opciones, condiciones y prácticas sexuales de los/las no sujetos". Y "los/las conservadores/as" como defensores/as de la "norma del sexo e imperativo heterosexual" son los/las encargados/as de controlar-vigilar las tecnologías biopolíticas del cuerpo-especie y de subordinar-docilizar las tecnologías disciplinarias del cuerpo-máquina. Es interesante observar cómo las nociones de verdad, poder y moral de las futuras profesoras evidencian una formación personal, académica, profesional y social "intrínsecamente vigilante de estas tácticas de poder y estrategias de saber". El "conservadurismo intelectual de los/ las sujetos" invisibiliza los conocimientos, competencias y actitudes hacia "los cuerpossexos-sexualidades de los/las no sujetos".

De la misma forma, las estudiantes de pedagogía "homofóbicas" visibilizan una aversión hacia la exposición pública de "los sexos-cuerpos-sexualidades homosexuales". Si bien las prácticas discursivas de los/las sujetos valoran "la facultad para elegir y ejercer libremente una opción, condición y/o práctica sexual", "sin ningún problema" se impugnan y objetan "las opciones, condiciones y prácticas sexuales de los/las no sujetos". En este sentido, los modelos explicativos y unidades de sentidos de la homofobia "naturalizan las sensaciones de asco o repugnancia ante las demostraciones públicas de cariño y afecto de los/las homosexuales", una aversión hacia los modos de ser-hacer-saber-decir de "los/las no sujetos" y una repulsión hacia las imágenes-apariencias-reacciones de sí mismos/as.

Por consiguiente, los contenidos programáticos sobre diversidad "quedan como letra muerta" en las líneas de formación, enfoques curriculares y perfiles de egreso de las carreras pedagógicas. "El currículo oculto de las discriminaciones y de las humillaciones 
sistemáticas" será el encargado de normalizar a "los estudiantes afeminados, a las ahombradas, y a los/las pelolais, ondulais, pokemones/as, góticos/as, emols, visual, etc.", que transitan por los contextos socioeducativos. Si bien las últimas investigaciones evidencian cambios radicales en las opciones, condiciones y prácticas sexuales de las nuevas generaciones, en las conformaciones familiares y en las actuaciones performativas sobre los sexos-cuerpos- sexualidades persiste en la formación personal, académica, profesional y social de los/las futuros/as profesores/as "un modelo único para pensar, sentir y vivir la sexualidad" y "un modelo de familia nuclear, procreadora y heterosexual".

\section{CONCLUSION}

Los/las estudiantes de pedagogía describen la lógica simbólica, normativa y económica de la heterosexualidad-homosexualidad. Una matriz de control, sujeción y producción de "sujetos y no sujetos", que identifica sus parámetros de (in)discreción (los dispositivos de la sexualidad) y sus comportamientos (in)aceptables (las tecnologías de poder-saber productivo). En este sentido, "los/las no sujetos serán aceptados/as por su comunidad siempre y cuando sean discretos/as y adecuados/as", puesto que sus demostraciones públicas de cariño y afecto generan "una situación difícil y chocante para los/las sujetos". "En la sociedad de normalización", el rechazo, resistencia y falta de preparación de los/las heterosexuales justifican las sanciones, prohibiciones e invisibilizaciones hacia los/las homosexuales.

De esta manera, los parámetros de (in)discreción y los comportamientos (in)aceptables "prohíben la exhibición pública de caricias y afectos" entre heterosexuales y homosexuales. Sin embargo, la discreción y lo aceptable quedan inscritos en los patrones socioculturales de los/las sujetos, quienes cristalizan-transparentan-legitiman sus opciones, condiciones y prácticas sexuales. Igualmente, los/las estudiantes de pedagogía "conservadores/as" muestran "una negación hacia la homosexualidad" y "los/las homofóbicos/as" declaran una aversión hacia "sus sexos-cuerpos-sexualidades". Así, "las sensaciones de asco y/o repugnancia de los/las sujetos", el reflejo de sus incapacidades físicas y psíquicas, justifican las discriminaciones y exclusiones hacia "los espacios reales o imaginarios de los/las no sujetos".

Es sugerente analizar cómo los modelos explicativos sobre los modos de ser-hacersaber-decir "objetivan" las operaciones representacionales asociadas a las relaciones de género, y las unidades de sentido de las imágenes-apariencias-reacciones de sí mismo/a "subjetivan" las experiencias identitarias relativas a la "diferencia-semejanza sexual". Estos procesos mantienen una alianza estratégica con el imperativo heterosexual y una complicidad con la norma del sexo, "el orden hegemónico de los/las sujetos" controlavigila y subordina-dociliza "las posibles transgresiones de los/las no sujetos". De este modo, los/as futuros/as profesores/as describen las conductas patológicas, inadecuadas, desagradables y amenazantes de los/las homosexuales, "una violencia simbólica" hacia las nociones de verdad, poder y moral de los/las heterosexuales. Así, la "naturaleza, existencia, operatividad y justificación de la masculinidad y feminidad" califica-circunscribe "la lógica binaria y relación de complementariedad entre sujetos", posiciona-demarca "sus sexos-cuerpos-sexualidades" y las regula-diferencia "ante las otras opciones, condiciones y prácticas sexuales". 
Por lo tanto, las operaciones representacionales y experiencias identitarias sobre heterosexualidad y homosexualidad de los/las estudiantes de pedagogía en los contextos de Formación Docente Inicial visibilizan "una pasión por la semejanza-heteronormatividad y una exaltación mascultista-homofóbica". Una formación personal, académica, profesional y social que transforma los conocimientos, competencias y actitudes sobre diversidad, respeto y/o tolerancia hacia el/la otro/a distinto/a, "en un híbrido aséptico, neutral, apolítico y asexuado". Estas prácticas discursivas legitiman "el currículo oculto de las discriminaciones" en los contextos socioeducativos, y vulneran los derechos democráticos y obligaciones ciudadanas de sus actores protagónicos/as.

\section{BIBLIOGRAFIA}

Avalos, B. (2002). Profesores para Chile, historia de un proyecto. Chile: Ministerio de Educación.

Bernard, M. (1997). Introducción a la lectura de la obra de René Kaës. Argentina: Ediciones Publikar.

Bourdieu, P. (2000). La Dominación Masculina. Barcelona: Editorial Anagrama S.A.

Butler, J. (2002). Cuerpos que importan. Sobre los límites materiales y discursivos del "sexo". Argentina: Editorial Paidós SAICF.

Cárdenas, A. (2001). Estudio comprensivo del discurso de estudiantes de pedagogía: su voz y el proceso de formación docente. Chile: Tesis de Magíster en Investigación Educativa. Universidad Academia de Humanismo Cristiano.

Castro, E. (2004). El vocabulario de Michel Foucault. Un recorrido alfabético por sus temas, conceptos y autores. Buenos Aires: Universidad Nacional de Quilmes.

Chartier, R. (1992). El mundo como representación: estudios sobre historia cultural. Barcelona: Gedisa.

Cherryholmes, C. (1999). Poder y crítica. Investigaciones postestructurales en educación. Barcelona: Pomares-Corredor. S.A.

Cox, C. (2003). Políticas educacionales en el cambio de siglo. Chile: Editorial Universitaria S.A.

Curiel, O. (2004). Identidades esencialistas o construcción de identidades políticas: El dilema de las feministas negras. Revista Electrónica $\mathrm{N}^{\circ} 36$.

Daniel, G. (2002). Investigación cualitativa y análisis crítico del discurso en educación. Perspectivas teóricas y estrategias metodológicas. Argentina: Universidad Nacional de Catamarca.

De Gialdino, V. (1992). Métodos cualitativos: los problemas teórico-metodológicos. Buenos Aires: Centro Editor de América Latina.

Delors, J. (2000) La educación encierra un tesoro. UNESCO.

Espinosa, Y. (2003). La política educativa perforada por la política de identidad en la era posidentitaria. Cuando al fin nos acomodamos en el barco ya tenemos que bajarnos. En Revista Interdisciplinaria de Estudios de Género. Vol. 1, $\mathrm{N}^{\circ} 1$.

Foucault, M. (1976). Vigilar y Castigar. México: Siglo XXI Editores.

Foucault, M. (1981). Historia de la sexualidad. La voluntad del saber. Volumen 1. México: Siglo Veintiuno Editores, S.A.

Foucault, M. (1987). Historia de la sexualidad. El uso de los placeres. Volumen 2. México: Siglo Veintiuno Editores, S.A.

Foucault, M. (1987). Historia de la sexualidad. La inquietud de sí. Volumen 3. México: Siglo Veintiuno Editores, S.A.

Foucault, M. (1992). Microfisica del Poder. Madrid: Ediciones La Piqueta. 
Foucault, M. (1997). La Arqueología del saber. México: Siglo Veintiuno Editores, S.A.

Freixas, A. y M. Fuentes-Guerra (1994). La reflexión sobre el sistema sexo/género. Un reto en la actual formación del profesorado. Revista de Educación $\mathrm{N}^{\circ} 304$.

Gasque, M. (1990). Freud y la homosexualidad. Revista Debate Feminista $\mathrm{N}^{\circ} 1$.

Hexagrama Consultores, FLACO, IESCO. (2006). Equidad de género y reformas educativas. Argentina, Chile, Colombia, Perú.

Hirigoyen, M. (1998). El Acoso Moral. España: Ediciones Paidós Ibérica. S.A.

Jodelet, D. (1989). La representación social: fenómenos, conceptos y teorías. Paris: Presses Universitaires.

Kemmis S. (1999) La investigación-acción y la política de la reflexión. España: Ediciones Akal S.A.

Lamas, M. Compiladora (1996). El género: la construcción cultural de la diferencia sexual. UNAM: Coordinación de Humanidades. Programa Universitario de Estudios de Género.

Lamas, M. (1998). Usos, dificultades y posibilidades de la categoría "género". Ecuador: Ediciones Abya-Yala.

Laurentis, T. (1991). El género en perspectiva: de la dominación universal a la representación múltiple. México: Universidad Autónoma de México.

Martínez, M. (2002). Algunos debates contemporáneos en torno a la categoría género y sus implicaciones para el contexto universitario. Revista Otras Miradas. Grupo de Investigación en Género y Sexualidad. GIGESEX. Facultad de Humanidades y Educación. Universidad de los Andes Mérida-Venezuela.

Matus, C. (2006). Problematizando al sujeto dentro del currículo. Programa de Doctorado. Facultad de Educación. Pontificia Universidad Católica de Chile.

Ministerio de Educación, Universidad Alberto Hurtado y Universidad Católica de Valparaíso (2006). Docentes para el Nuevo Siglo. Hacia una política de desarrollo profesional docente.

Ministerio de Educación. (2005). Informe Comisión sobre Formación Docente Inicial. Chile.

Moscovici, S. (1986). Psicología social. Barcelona: Paidós.

Neri. (1997). Grupo. Manual de psicoanálisis de grupo. Argentina: Ediciones Nueva Visión SAIC

Pérez, A. (1996). El pensamiento práctico del profesor. Implicaciones en la formación del profesorado. Madrid: Ediciones Narcea.

Piña, C. (1988). La construcción del 'sí mismo' en el relato autobiográfico. Chile: FLACSO Documento de Trabajo $\mathrm{N}^{\circ} 383$.

Sandín, M. (2003). Investigación cualitativa en educación. Fundamentos y tradiciones. Madrid: McGraw- Hill/Interamericana de España, S.A.U.

Scott, J. (1990). El género: una categoría útil para el análisis histórico. En Historia y género: las mujeres en la Europa moderna y contemporánea de Amelang y Nash:. Ediciones Alfons el Magnánim.

Talburt, S. y R. Steinbert (2005). Pensando Queer. Sexualidad, cultura y educación. Barcelona: Graó.

Torres, A. (1992). El malentendido de la homosexualidad. Revista Debate Feminista $\mathrm{N}^{\circ} 5$.

Tuozzo, C. (2000). "Olvidemos a los profesores": La identidad femenina a fines del siglo XX. Revista Universum $\mathrm{N}^{\circ}$ 15: 323-330.

UNESCO (2001). La igualdad de género en la Educación Básica. Chile: Oficina Regional de Educación para América Latina y el Caribe.

Vaillant, D. (2005). Formación de docentes en América Latina. Barcelona: Ediciones Octaedro.

Vallejo, A., R. Rey y F. López (2001). Conocimientos de estudiantes universitarios sobre mitos de la sexualidad. Revista de Educación Educar $\mathrm{N}^{\circ} 17$.

Wodak, R. y M. Meyer (2003). Métodos de Análisis Crítico del Discurso. Barcelona: Editorial Gedisa S.A. 
Zeichner, K. y D. Liston (1995). Enseñar a Reflexionar a los Futuros Docentes. EE.UU.: Magisterio de la Universidad de Wisconsin, Madison.

Zerón, A. (2006). Sentido de la violencia escolar en Chile: un estudio de sociología comprensiva. Chile: Tesis Doctoral. Pontificia Universidad Católica de Chile.

Zizek, S. (2001). El sujeto espinoso. El centro ausente de la ontología política. Buenos Aires: Editorial Paidós SAICF. 